Blut (1984) 48: 181

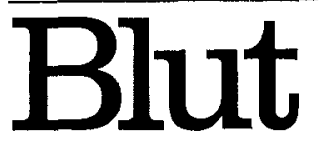

Springer-Verlag 1984

\title{
Erratum
}

\section{The Compactness of Populations of Neutrophilic} Leucocytes as Revealed by the New Azure B-Eosine Stain, Pappenheim's Stain and the Peroxidase Reaction

H. Kurz and O. Leder

Blut (1984) 48: 49-52

The composition of Plasmagel given on page 49 in Material and Methods, lines 4 and 5 is

$\begin{array}{lc}\text { gelatine } & 15 \mathrm{~g} \\ \mathrm{NaCl} & 3.5 \mathrm{~g} \\ \mathrm{KCl} & 0.37 \mathrm{~g} \\ \mathrm{CaCl}_{2} & 1.0 \mathrm{~g} \\ \text { distilled water ad } & 500 \mathrm{ml}\end{array}$

